\title{
IRRIGATION WATER SUPPLY AND DEMAND DATA FOR 1976, 1980, AND 1984 FOR THE WESTERN SAN JOAQUIN VALLEY, CALIFORNIA
}

By William E. Templin, Thomas C. Haltom, and others

U.S. GEOLOGICAL SURVEY

Open-File Report 94-335

Prepared in cooperation with the

SAN JOAQUIN VALLEY DRAINAGE PROGRAM 


\section{U.S. DEPARTMENT OF THE INTERIOR BRUCE BABBITT, Secretary}

\section{U.S. GEOLOGICAL SURVEY}

GORDON P. EATON, Director

Any use of trade, product, or firm names in this publication is for descriptive purposes only and does not imply endorsement by the U.S. Government.

For sale by the U.S. Geological Survey Earth Science Information Center Open-File Reports Section Box 25286, MS 517

Denver Federal Center

Denver, CO 80225

For additional information write to:

District Chief

U.S. Geological Survey

Federal Building, Room W-2233

2800 Cottage Way

Sacramento, CA 95825 


\title{
CONTENTS
}

\author{
Abstract 1 \\ Introduction 1 \\ Methods of data collection 6 \\ Compression-decompression program 7 \\ Menu method 7 \\ DOS method 7 \\ References cited $\mathbf{8}$
}

\section{FIGURES}

1. Map showing sections within the study area for which data were available for 19842

2. Map showing detailed analysis unit boundaries 3

3. Chart showing files contained on the diskette 7

4. Chart showing menus to select drive and files 7

\section{TABLES}

1. List of water districts, format of provided records, and years data are available 4 and diskette

2. Summary of deliveries and irrigated acres $\mathbf{5}$ and diskette

3. Data file of surface-water deliveries by water district, year, location, and amount of water supplied diskette

4. Data file of irrigated crop acreage by water district, year location acres of crop, crop code, crop-water requirement, and water demand diskette

5. Crop codes diskette

6. Crop-water requirements by detailed analysis unit diskette

\section{Conversion Factors}

\begin{tabular}{rcl}
\hline Multiply & By & To obtain \\
\hline \multirow{2}{*}{ acres } & AREA & square feet \\
& 43,560 & square meters \\
& 4,047 & square miles \\
& 0.001562 & hectare \\
& 0.4047 & million gallons per day \\
thousand acre-ft/yr & FLOW & \\
& & \\
\end{tabular}




\title{
IRRIGATION WATER SUPPLY AND DEMAND DATA FOR 1976, 1980, AND 1984 FOR THE WESTERN SAN JOAQUIN VALLEY, CALIFORNIA
}

\author{
By William E. Templin, Thomas C. Haltom, and others
}

\begin{abstract}
This report presents the irrigation water supply and demand data for 1976, 1980, and 1984 for 32 water districts in the western San Joaquin Valley, California. Available data are totaled for each water district for those three years. The complete data base is given by water district for each township, range, and section in the rectangular system for the subdivision of public lands. These data were compiled for use in a ground-water-flow model, compilation of a water-budget, and use by the San Joaquin Valley Drainage Program in a study of water management in the western San Joaquin Valley, California. The data are presented in a computer-readable format to improve data utilization and to condense the information so that it can be more readily distributed to users.
\end{abstract}

\section{INTRODUCTION}

Data were compiled in cooperation with the San Joaquin Valley Drainage Program for irrigation water supply, water demand, and related information for the years 1976, 1980, and 1984 for the western San Joaquin Valley, California. Table 1 is a summary of water districts surveyed and years of available data for these water districts. In this report, data are compiled for each of 32 water districts by year (tables 2 and 3). The complete data base is given, by water district, for each township, range, and section in the rectangular system for the subdivision of public lands (tables 3 and 4). This report was compiled to make these data available to the public. These data were compiled for use in a ground-water-flow model (Belitz and Heimes, 1990), estimation of a water budget (Gronberg and Belitz, 1992), and for use by the San Joaquin Valley Drainage Program (1989) in the study of water management in the western San Joaquin Valley, California. The study area is in the western part of the San Joaquin Valley, and is bounded on the west by the Coast Range and includes the western parts of Stanislaus, Merced, Madera, Fresno, Kings, Tulare, and Kern Counties. The study area extends from 40 miles northwest of the city of Merced to 25 miles south of the city of Bakersfield. The sections within the study area for which data are available for 1984 are shown in figure 1. Detailed analysis units (DAU), designated by the California Department of Water Resources on the basis of similarities in water supply and water-use characteristics (California Department of Water Resources, 1982) are shown in figure 2.

Volumes of water delivered within the study area by water district and crop acreage were compiled from water district records. Annual crop water requirements (CWR), or unit-applied water averages by region were obtained from the California Department of Water Resources, San Joaquin Valley District, Fresno, California. Each CWR was used with the appropriate crop acreages to estimate crop water demands (tables 5 and 6).

For convenience, tables 1 and 2 are duplicated in this text. They are also included on the diskettes accompanying this report. Because of bulk, tables 3 through 6 are contained only on diskettes. The diskettes require an IBM-compatible microcomputer with the MS-DOS operating system. Presenting data in this computer-readable format improves the ease of utilizing the data and condenses the information so that it can be easily distributed to users.

The authors wish to thank the many individuals and water districts for their cooperation in the compilation of the information used in this report. Much 


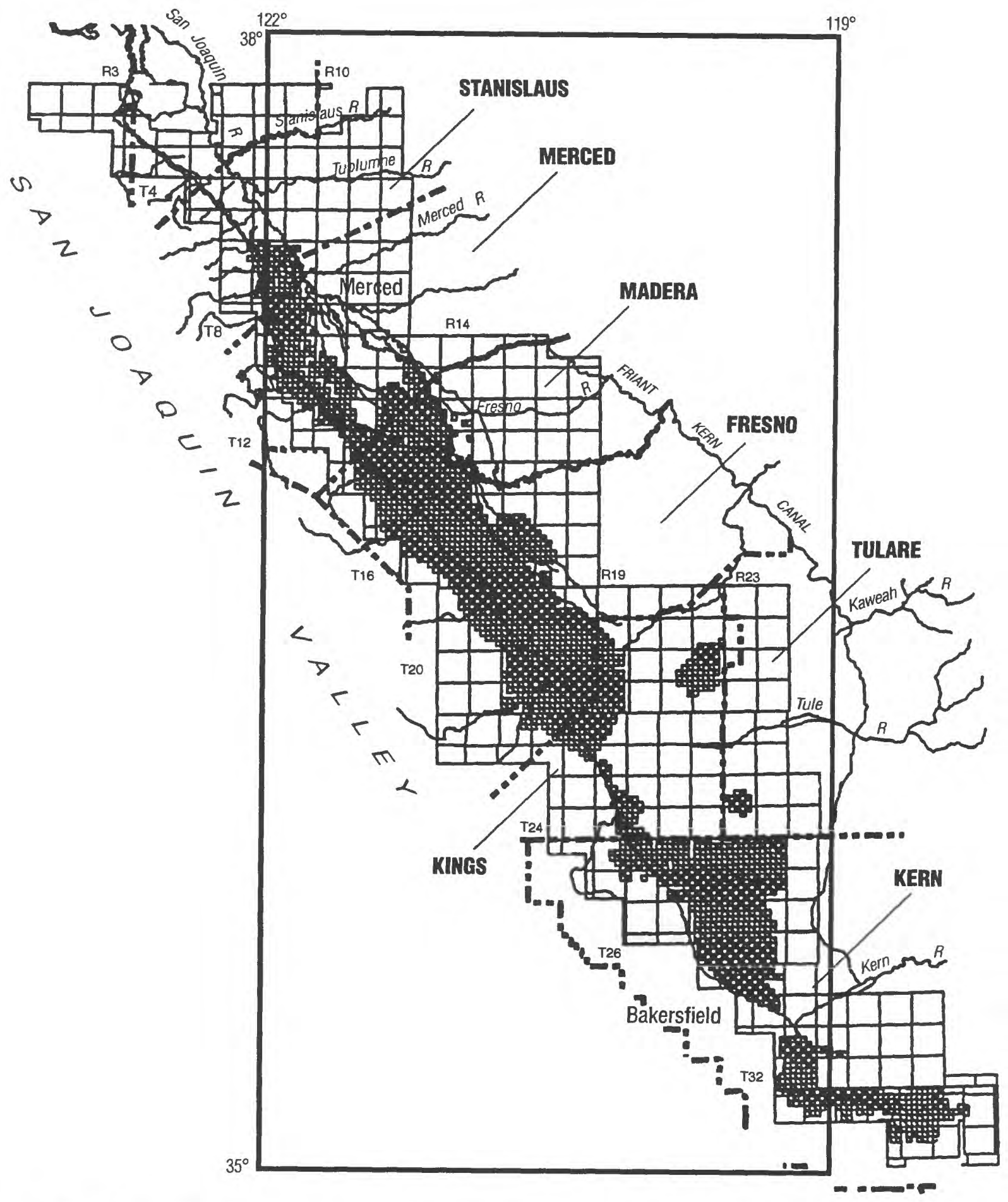

Figure 1. Sections within the study area for which data were available for 1984. 


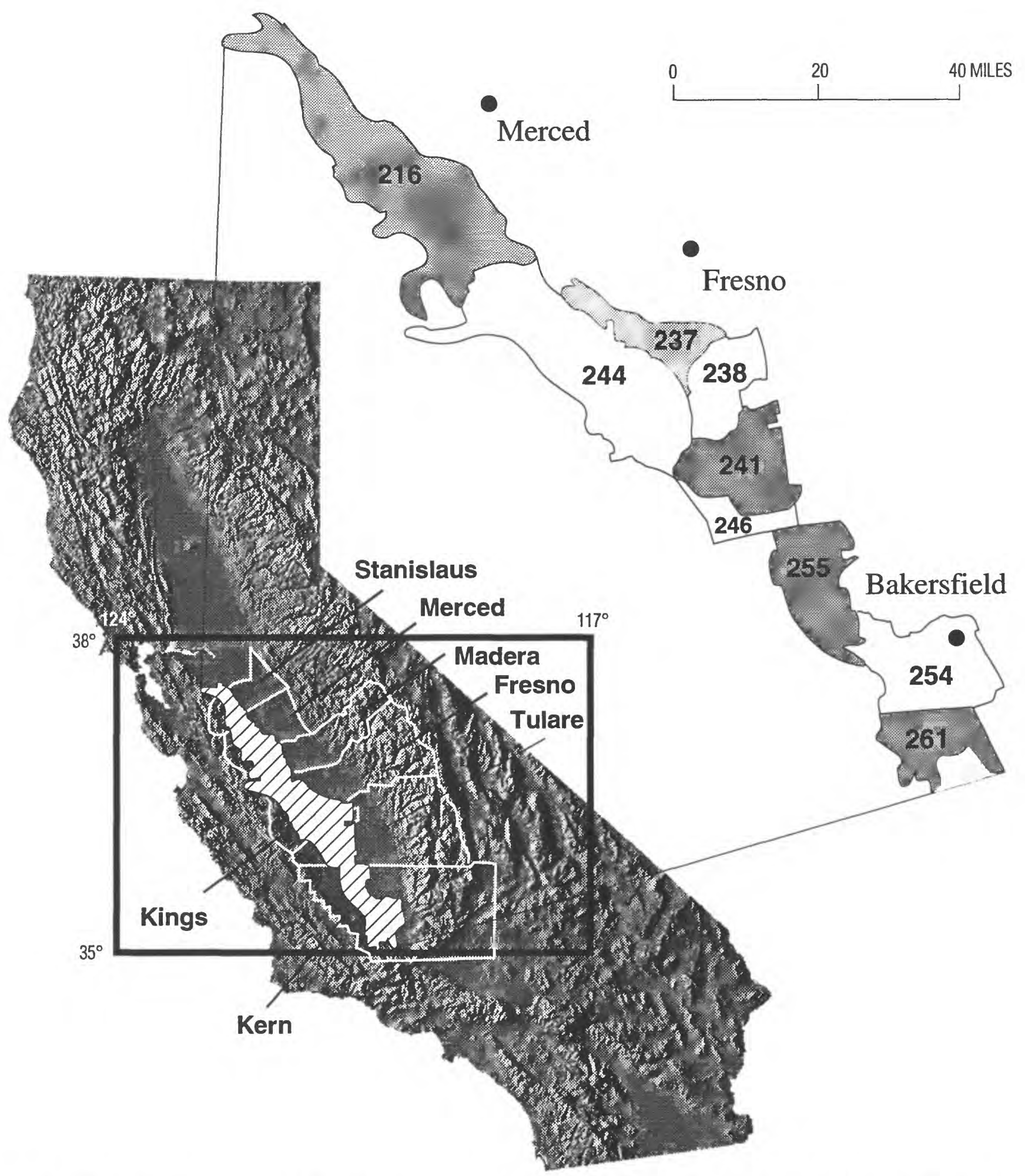

Figure 2. Detailed analysis unit (DAU) boundaries. (DAUs are the smallest areas used by the California Department of Water Resources for aggregation of water use related data.) 
Table 1. List of water districts, format of provided records, and years data are available (see tables 2,3 , and 4)

[CC, canal company; CWD, commercial water district; ID, irrigation district; IWD, irrigation water district; WD, water district; WSD, water storage district. Years are calendar years]

\begin{tabular}{|c|c|c|c|}
\hline Water district & $\begin{array}{c}\text { Photocopy } \\
\text { or original files } \\
\text { (years) }\end{array}$ & $\begin{array}{l}\text { Other format } \\
\text { (years) }\end{array}$ & Notes \\
\hline Alpaugh ID & 80,84 & & \\
\hline Angiola WD & & & No usable data provided \\
\hline Atwell Island WD & & & Data incomplete \\
\hline Broadview WD & $76,80,84$ & & \\
\hline Buena Vista WSD & 76,80 & 84 & Computer output ${ }^{1}$ \\
\hline Centinella WD & $76,80,84$ & & \\
\hline Central California ID & 84 & & \\
\hline Corcoran ID & & & No usable data provided \\
\hline Davis WD & $76,80,84$ & & \\
\hline Dudley Ridge WD & $76,80,84$ & & \\
\hline Eaglefield WD & $76,80,84$ & & \\
\hline Firebaugh CC & $76,80,84$ & & \\
\hline Foothill WD & $76,80,84$ & & \\
\hline Fresno Slough WD & 80,84 & & \\
\hline Grasslands WD & & & No usable data provided \\
\hline Hacienda WD & & & No usable data provided \\
\hline Henry Miller WD & $76,80,84$ & & \\
\hline James ID & 80,84 & & (2) \\
\hline Kern Delta WD & & & Unable to contact \\
\hline Kings County CC & & & No usable data provided \\
\hline Kings County WD & & & No usable data provided \\
\hline Laguna ID & & & No usable data provided \\
\hline Laguna WD & 80,84 & & \\
\hline Lakeside IWD & 80,84 & & \\
\hline Lost Hills WD & $76,80,84$ & & \\
\hline Melaga WD & & & No usable data provided \\
\hline Mercy Springs WD & $76,80,84$ & & \\
\hline Mustang WD & $76,80,84$ & & \\
\hline Orestimba WD & $76,80,84$ & & \\
\hline Oroloma WD & 80,84 & & \\
\hline Pacheco WD & $76,80,84$ & & \\
\hline Panoche WD & 80 & 84 & (1) \\
\hline Quinto WD & $76,80,84$ & & \\
\hline Riverdale ID & & & Unable to contact \\
\hline Romero WD & $76,80,84$ & & \\
\hline Salado WD & $76,80,84$ & & \\
\hline Salyer WD & & & Unable to contact \\
\hline San Luis CC & & & $(2,3)$ \\
\hline San Luis WD & 80,84 & & \\
\hline Santa Nella CWD & & & Unable to contact \\
\hline Santa Rita WD & & & Unable to contact \\
\hline Semitropic WSD & $76,80,84$ & & \\
\hline Stratford ID & & & Unable to contact \\
\hline Sunflower WD & $76,80,84$ & & \\
\hline Traction Ranch WD & & & Unable to contact \\
\hline Tranquillity ID & 76,80 & 84 & Computer output ${ }^{1}$ \\
\hline Tulare Lake Basin WSD & & & No usable data provided \\
\hline Upper San Jose WD & & & Unable to contact \\
\hline Westlands WD & 80 & ${ }^{4} 76,84$ & \\
\hline Wheeler Ridge-Maricopa WSD & $76,80,84$ & & \\
\hline Widren WD & $76,80,84$ & & \\
\hline
\end{tabular}

${ }^{1}$ Paper copy provided.

${ }^{2}$ Original files microfilmed by U.S. Geological Survey personnel at water-district office.

${ }^{3}$ Data not in usable format.

${ }^{4}$ Microfilm provided for 1976; computer tape provided for 1984. 
Table 2. Summary of deliveries and irrigated acres

[CC, canal company; ID, irrigation district; IWD, irrigation water district; WD, water district; WSD, water storage district; acre-ft, acre-foot. Years are calendar years]

\begin{tabular}{|c|c|c|c|c|c|c|c|}
\hline Water district & Year & $\begin{array}{l}\text { Deliveries } \\
\text { (acre-ft) }\end{array}$ & $\begin{array}{l}\text { Irrigated } \\
\text { acres }\end{array}$ & Water district & Year & $\begin{array}{l}\text { Deliveries } \\
\text { (acre-ft) }\end{array}$ & $\begin{array}{l}\text { Irrigated } \\
\text { acres }\end{array}$ \\
\hline Alpaugh ID & 80 & $11,684.52$ & $6,200.50$ & Mustang WD & 80 & $14,938.00$ & $4,142.00$ \\
\hline Alpaugh ID & 84 & $16,626.26$ & $6,812.50$ & Mustang WD & 84 & $21,720.10$ & $4,218.30$ \\
\hline Broadview WD & 76 & $28,710.00$ & $9,019.00$ & Orestimba WD & 76 & $23,902.00$ & $5,688.00$ \\
\hline Broadview WD & 80 & $26,663.50$ & $8,871.00$ & Orestimba WD & 80 & $19,045.00$ & $6,102.00$ \\
\hline Broadview WD & 84 & $18,004.30$ & $8,711.00$ & Orestimba WD & 84 & $17,176.60$ & $5,694.50$ \\
\hline Buena Vista WSD & 76 & $20,964.40$ & $42,128.50$ & Oroloma WD & 80 & $5,479.00$ & $1,014.40$ \\
\hline Buena Vista WSD & 80 & $74,333.80$ & $41,760.00$ & Oroloma WD & 84 & $4,607.24$ & $1,014.40$ \\
\hline Buena Vista WSD & 84 & $75,860.59$ & $40,986.00$ & Pacheco WD & 76 & $19,491.96$ & $6,478.00$ \\
\hline Centinella WD & 76 & $3,675.00$ & 816.00 & Pacheco WD & 80 & $13,538.87$ & $5,261.00$ \\
\hline Centinella WD & 80 & $1,841.00$ & 746.00 & Pacheco WD & 84 & $15,821.92$ & $4,519.99$ \\
\hline Centinella WD & 84 & $1,805.00$ & 684.00 & Panoche WD & 80 & $100,993.00$ & $30,655.01$ \\
\hline Central California ID & 84 & $452,123.40$ & $153,393.30$ & Panoche WD & 84 & $105,823.16$ & $31,774.04$ \\
\hline Davis WD & 76 & $5,936.00$ & $1,365.00$ & Quinto WD & 76 & $8,835.00$ & $2,087.00$ \\
\hline Davis WD & 80 & $4,270.00$ & $1,178.00$ & Quinto WD & 80 & $6,800.00$ & $2,136.00$ \\
\hline Davis WD & 84 & $4,214.00$ & $1,113.00$ & Quinto WD & 84 & $9,610.00$ & $2,367.00$ \\
\hline Dudley Ridge WD & 76 & $72,632.36$ & $26,699.00$ & Romero WD & 76 & $6,240.00$ & $1,327.00$ \\
\hline Dudley Ridge WD & 80 & $80,360.34$ & $23,544.00$ & Romero WD & 80 & $3,849.00$ & $1,093.00$ \\
\hline Dudley Ridge WD & 84 & $64,606.47$ & $19,814.00$ & Romero WD & 84 & $4,834.40$ & 918.00 \\
\hline Eaglefield WD & 76 & $4,204.00$ & $1,589.00$ & Salado WD & 76 & $12,705.90$ & $3,277.00$ \\
\hline Eaglefield WD & 80 & $3,734.00$ & $1,340.00$ & Salado WD & 80 & $8,643.00$ & $3,209.00$ \\
\hline Eaglefield WD & 84 & $4,281.00$ & $1,549.36$ & Salado WD & 84 & $7,024.50$ & $2,992.80$ \\
\hline Firebaugh CC & 76 & $62,057.20$ & $15,889.00$ & San Luis WD & 80 & $123,356.00$ & $52,777.00$ \\
\hline Firebaugh CC & 80 & $59,670.70$ & $13,723.00$ & San Luis WD & 84 & $155,099.01$ & $53,035.63$ \\
\hline Firebaugh CC & 84 & $56,577.90$ & $20,090.60$ & Semitropic & 76 & $59,374.15$ & $115,052.00$ \\
\hline Foothill WD & 76 & $10,750.00$ & $3,028.00$ & Semitropic & 80 & $165,817.51$ & $140,622.00$ \\
\hline Foothill WD & 80 & $10,618.00$ & $3,342.00$ & Semitropic & 84 & $197,806.82$ & $217,900.00$ \\
\hline Foothill WD & 84 & $15,150.60$ & $3,601.00$ & Sunflower WD & 76 & $18,879.00$ & $3,306.00$ \\
\hline Fresno Slough WD & 80 & $4,484.26$ & $1,199.00$ & Sunflower WD & 80 & $13,952.00$ & $4,192.00$ \\
\hline Fresno Slough WD & 84 & 508.56 & $1,161.00$ & Sunflower WD & 84 & $21,256.60$ & $4,048.70$ \\
\hline Henry Miller WD & 76 & $67,563.30$ & $30,425.00$ & Tranquillity ID & 76 & $26,323.92$ & $10,552.00$ \\
\hline Henry Miller WD & 80 & $50,402.87$ & $30,087.00$ & Tranquillity ID & 80 & $23,346.28$ & $9,391.00$ \\
\hline Henry Miller WD & 84 & $64,685.54$ & $27,040.00$ & Tranquillity ID & 84 & $36,903.29$ & $8,902.00$ \\
\hline James ID & 80 & $22,842.10$ & $11,316.00$ & Westlands WD & 76 & $984,452.39$ & $460,409.00$ \\
\hline James ID & 84 & $40,066.13$ & $15,456.00$ & Westlands WD & 80 & $1,098,585.26$ & $560,781.00$ \\
\hline Laguna WD & 80 & 798.75 & 355.00 & Westlands WD & 84 & $1,382,697.75$ & $547,588.00$ \\
\hline Laguna WD & 84 & $2,191.00$ & 307.00 & Wheeler Ridge- & & & \\
\hline Lakeside IWD & 80 & $50,661.85$ & $32,637.00$ & Maricopa WSD & 76 & $228,461.26$ & $108,643.00$ \\
\hline Lakeside IWD & 84 & $58,398.46$ & $33,088.00$ & Wheeler Ridge- & & & \\
\hline Lost Hills WD & 76 & $86,233.00$ & $50,152.00$ & Maricopa WSD & 80 & $226,020.87$ & $113,118.00$ \\
\hline Lost Hills WD & 80 & $122,380.00$ & $57,970.00$ & Wheeler Ridge- & & & \\
\hline Lost Hills WD & 84 & $147,991.00$ & $53,155.00$ & Maricopa WSD & 84 & $225,012.97$ & $119,380.00$ \\
\hline Mercy Springs WD & 76 & $11,994.00$ & $2,958.00$ & Widren WD & 76 & $2,876.40$ & 765.00 \\
\hline Mercy Springs WD & 80 & $13,921.00$ & $2,865.00$ & Widren WD & 80 & $1,545.30$ & 765.00 \\
\hline Mercy Springs WD & 84 & $11,212.90$ & $2,162.40$ & Widren WD & 84 & $7,860.38$ & 662.00 \\
\hline Mustang WD & 76 & $17,890.00$ & $4,175.00$ & & & & \\
\hline
\end{tabular}


assistance in the data collection and compilation efforts was received from Alysa M. Fisher, Deborah H. Horner, Joelle L. Wilkes, and Lisa L. Zaffran, former U.S. Geological Survey student assistants. Terry Erlewine (California Department of Water Resources, San Joaquin District, Fresno, California) was especially helpful in providing regional estimates of crop water requirements and related information from the California Department of Water Resources Surface Water Allocation Model.

\section{METHODS OF DATA COLLECTION}

The standard approach for collecting and synthesizing the water-use and crop information was to contact each water district to determine how much needed information they had and the format and storage media they used. Then, the best approach for automating the available information was determined. Ideally, this information included water-delivery records (organized by grower and diversion location) and a map showing the water-supply delivery system and locations of the last point at which metered (or estimated) delivery volumes were recorded. Collected data were combined to reflect the quantity of water delivered and the acreage of crops grown within a geographic area (township, range, and section).

The level of detail of available crop acreage and water-delivery data varies among water districts. Some water districts record only the total acreage of crops grown each year; others record the acreage in each field. Water-delivery information also varies. Many districts keep daily or monthly water-delivery data for each field or geographic section; other districts record only the quantity of water delivered monthly to each grower.

Growers in many parts of the study area commonly transfer water from section to section using ditches, pipelines, and canals, as needed. Therefore, reliable relations between quantity of water delivered to diversion gates and the sections irrigated from each diversion were often difficult to establish. California Department of Water Resources land-use maps and water-district ownership maps (if available) were used to approximate distribution of annual water-delivery totals to fields within a district's area. When a single field covered more than one geographic section, the water demand was distributed proportional to the area of that crop within each section.
If only the total annual water delivered by the water district was known, (eq. 1 and 2) water deliveries to individual fields or geographic sections were estimated. Equation 1 was used to estimate a district average delivery per acre for eåch crop. Given total acreage of each crop within each section, total water deliveries for a section then were determined using equation 2 .

$$
D t=(A t 1 * R 1 * X)+(A t 2 * R 2 * X)+(A t n * R n * X)
$$

$$
D s=(A s 1 * R 1 * X)+(A s 2 * R 2 * X)+(A s n * R n * X){ }^{(2)}
$$

\begin{tabular}{|c|c|c|}
\hline$t$ & is & $\begin{array}{l}1 \text { water deliveries for a } \\
\text { strict, in acre-ft, }\end{array}$ \\
\hline At 1 & is & es for crop 1 \\
\hline At 2 & is & r crop 2 , \\
\hline Atn & is & s for crop $n(3 \ldots)$, \\
\hline$R 1$ & is & theoretical CWR for crop 1 , \\
\hline$R 2$ & is & for crop 2 , \\
\hline$R n$ & is & NR for crop $n(3 \ldots)$, \\
\hline$Y$ & is & $\begin{array}{l}\text { eoretical CWR for } \\
\text { deliveries, }\end{array}$ \\
\hline 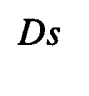 & is & $\begin{array}{l}\text { total annual water deliveries for a } \\
\text { section, in acre-feet, }\end{array}$ \\
\hline & & acres in a section for crop 1 , \\
\hline & & section for crop 2 \\
\hline & & in a section for crop $n(3 \ldots)$. \\
\hline
\end{tabular}

where

Total crop water demand was based on annual areawide averages of unit applied water by crop (CWR) and crop acreages (California Department of Water Resources, 1986, p. 21). This was calculated by multiplying the CWR for the specific year and geographic location of the water district by the appropriate crop acreage. The total calculated water demand for the geographic sections then was verified against the total water supply reported by the water district.

Each water district receiving Central Valley Project water is required by the U.S. Bureau of Reclamation to keep annual totals for each irrigated crop. Some water districts meet this requirement with annual crop maps showing the location of each grower's fields and acreage, as well as types of crops grown. For the majority of the water districts, how- 
ever, less detailed records are kept. For this study, acreage of crops grown was estimated by analyzing each water district's records.

Data files were checked for data-entry errors and compared with the annual totals reported by the water districts, the California Department of Water Resources, and the U.S. Bureau of Reclamation. The data were entered into ARC/INFO, a geographic information system used by the U.S. Geological Survey and others (Templin, 1986).

The quality-control goal for compiled data was to be within 5 percent of the total reported by each water district. The totals compiled for this study usually are near 100-percent agreement with annual totals reported by water districts. If a water district receives water only from the California Department of Water Resources or the U.S. Bureau of Reclamation, the yearly crop distribution and water-delivery totals from these agencies were used as a check to determine the accuracy of the compiled totals. Most discrepancies between water district and State (or Federal) agency water-supply totals were attributed to variations in meters and meter-maintenance practices or recycling water.

\section{COMPRESSION-DECOMPRESSION PROGRAM}

The compression-decompression program "LHarc" is the program used to compress the data files into self-extracting libraries. The LHarc program and documentation may be obtained by copying LH113C.EXE to any directory on either the hard disk or a diskette, typing 'LH113C', and pressing the enter key. There is enough room on the irrigation diskette for the program and documentation, which require approximately 2.5 megabytes.

There are two methods to decompress the IRRIG.EXE file. The "menu method" requires a version of MS-DOS more recent than 2.0, and the "DOS method" is used for versions 2.0 or earlier. Figure 3 lists all files contained on the diskette.

The compression-decompression program, LHarc, is copyrighted by Haruyasu Yoshizaki. Permission to copy is granted freely, provided that all copies contain the statement, "Copyright by Haruyasu Yoshizaki."

$\begin{array}{lll}\text { TABL1256 } & \text { EXE } & 7148 \\ \text { TABLE3 } & \text { EXE } & 43975 \\ \text { TABLE4 } & \text { EXE } & 183228 \\ \text { LH113C } & \text { EXE } & 36964 \\ \text { IRRIG } & \text { BAT } & 255 \\ \text { HEADER3 } & & 1022 \\ \text { HEADER4 } & & 1499 \\ \text { REPORT } & \text { TXT } & 16550\end{array}$

Figure 3. Files contained on the diskette.

\section{A SELECTION OF DRIVE}

(1) DRIVE C:

(2) DRIVE D:

(3) EXIT

\section{$B$ SELECTION OF FILE(S)}
(1) TABLES 1,2,5, AND 6
(2) TABLE 3 (DELIVERIES)
(3) TABLE 4 (CROPS)
(4) EXIT

Figure 4. Menus to select drive and files.

\section{MENU METHOD}

To implement the decompression program, place the diskette in drive A:, attach to A:, type 'IRRIG', and press the enter key. The menu shown in figure $4 A$ will appear. REPLY.COM is a program borrowed from Wolverton (1986) that operates the menu. When either drive $C$ : or $D$ : is selected, the menu shown in figure $4 B$ will appear. By selecting choices from both menus, each group of files may be placed on either or both drives in any convenient combination.

Decompressing the self-extracting files will create an IRRIG directory on the drive(s). This directory will contain the decompressed table files totaling $2,500,000$ bytes of disk space.

\section{DOS METHOD}

Files can be decompressed and placed in any drive having sufficient free space by copying the ap- 
propriate filename.EXE to a subdirectory of that drive and then executing by typing the file name. For example, if the table files are to be placed in a subdirectory named IRRIG on the D: drive, copy the file IRRIG.EXE to D:IIRRIG; attach to that directory; type 'IRRIG', and press the enter key. Computer instructions contained within IRRIG.EXE will cause the decompression of this file and place decompressed files into D:URRIG.

\section{References Cited}

Belitz, Kenneth, and Heimes, F.J., 1990, Character and evolution of the ground-water flow system in the central part of the western San Joaquin Valley, California: U.S. Geological Survey Water-Supply Paper 2348, 28 p.

California Department of Water Resources, 1982, The hydrologic-economic model of the San Joaquin Valley: California Department of Water Resources Bulletin 214, 177 p.
California Department of Water Resources, 1986, Crop water use in California: California Department of Water Resources Bulletin 113-4, 116 p.

Gronberg, J.M., and Belitz, Kenneth, 1992, Estimation of a water budget for the central part of the western San Joaquin Valley, California: U.S. Geological Survey Water-Resources Investigations Report 91-4192, $22 \mathrm{p}$.

San Joaquin Valley Drainage Program, 1989, Preliminary planning alternatives for solving agricultural drainage and drainage-related problems in the San Joaquin Valley: San Joaquin Valley Drainage Program, Executive Summary and 5 chapters.

Templin, W.E., 1986, Water-use information for California: U.S. Geological Survey Open-File Report 86-483, $6 \mathrm{p}$.

Wolverton, Van, 1986, Supercharging MS-DOS: Redmond, Washington, Microsoft Press, 300 p. 